\title{
Shear Bond Strength of Dental Porcelains to Nickel-Chromium Alloys
}

\author{
Ricardo Alves do PRADO ${ }^{1}$ \\ Heitor PANZERI ${ }^{2}$ \\ Alfredo Julio FERNANDES NETO ${ }^{1}$ \\ Flávio Domingues das NEVES ${ }^{1}$ \\ Marlete Ribeiro da SILVA ${ }^{1}$ \\ Gustavo MENDONÇA ${ }^{1}$ \\ ${ }^{1}$ Department of Occlusion, Fixed Prosthesis and Dental Materials, Faculty of Dentistry, \\ Federal University of Uberlândia, Uberlândia, MG, Brazil \\ ${ }^{2}$ Department of Dental Materials and Prosthodontics, Faculty of Dentistry of Ribeirão Preto, \\ University of São Paulo, Ribeirão Preto, SP, Brazil
}

\begin{abstract}
The continuous technological advance and increasing availability of new base metal alloys and ceramic systems in the market, coupled to the demands of daily clinical practice, have made the constant evaluation of the bond strength of metal/porcelain combinations necessary. This study evaluated the metal/porcelain shear bond strength of three ceramic systems (Duceram, Williams and Noritake) in combination with three nickel-chromium (Ni-Cr) alloys (Durabond, Verabond and Viron). Thirty cast cylinder specimens (15 mm high; $6 \mathrm{~mm}$ in diameter) were obtained for each alloy, in a way that 10 specimens of each alloy were tested with each porcelain. Bond strength was measured with an Emic screw-driven mechanical testing machine by applying parallel shear forces to the specimens until fracture. Shear strength was calculated using the ratio of the force applied to a demarcated area of the opaque layer. Mann-Whitney $\mathrm{U}$ test was used for statistical analysis of the alloy/ceramic combinations $(\mathrm{p}<0.05)$. Viron/Noritake had the highest shear bond sregnth means $(32.93 \mathrm{MPa})$, while Verabond/Duceram $(16.31 \mathrm{MPa})$ presented the lowest means. Viron/Noritake differed statistically from other combinations $(\mathrm{p}<0.05)$. Viron/Duceram had statistically significant higher bond strengths than Verabond/Duceram, Verabond/ Williams and Durabond/Noritake $(p<0.05)$. It was also found significant difference $(p<0.05)$ between Verabond/Noritake, Verabond/ Duceram and Durabond/Noritake. No statistically significant difference $(\mathrm{p}>0.05)$ were observed among the other combinations. In conclusion, the Noritake ceramic system used together with Viron alloy presented the highest resistance to shear forces, while Duceram bonded to Verabond presented the lowest bond strength. Viron/Duceram and Verabond/Noritake provided intermediate results. The combinations between the Williams ceramic system and Ni-Cr alloys had similar shear strengths among each other.
\end{abstract}

Key Word: porcelain, metal alloy, metal/porcelain interface, shear bond strength.

\section{INTRODUCTION}

The alternative alloys for fabrication of metalceramic restorations became more popular in $1960 \mathrm{~s}$ after the costs of the gold alloys increased. The advantages and properties of base metal alloys have been reported $(1,2)$. Their mechanical properties enable the fabrication of restorations with greater rigidity and less thickness (2). The disadvantages include the potential biologic hazards, difficult handling and uncontrolled chromium oxide formation $(3,4)$.
Nickel-chromium (Ni-Cr) and cobalt-chromium (Co-Cr) alloys are the most used when cost and rigidity are considered. However, these alloys are not universally accepted for casting because they contain beryllium (Be) and other substances that can be harmful (4). It is also difficult to deal with these alloys in the laboratory because of their hardness, rendering necessary accurate casting and preparation procedures prior to firing the porcelain (3).

In Dentistry, the foremost studies proposed the use of feldspathic porcelain (pure) in combination with 
a framework fabricated in a precious metal such as platinum for preparation of complete crowns (5-7). This type of porcelain provided better esthetic than that offered by the available resins (methyl methacrylate) for restoration of anterior teeth.

Studies have attempted to explain the nature of the composition that leads to adhesion in the metal/ ceramic interface $(3,8)$. The success of porcelainfused-to-alloy restorations depends on the success of the bond between the ceramic and metal substructure (1). The chemical compatibility between metal and porcelain allows the restoration to resist thermal stress and mechanical forces (9), including a fusing temperature of the porcelain that does not cause distortion of the metal substructure and contraction of the porcelain that can be resisted by the metal (9).

The purpose of this study was to evaluate the shear bond strength of three ceramic systems to three Ni-Cr alloys.

\section{MATERIAL AND METHODS}

Three base metal alloys were selected: Durabond (Comercial Odonto Import Ltd., São Paulo, SP, Brazil), Verabond (Aalba Dent Inc., Cordelia, CA, USA) and Viron (BEGO, Bremer Goldschlagerei, Germany). Ten specimens of each metal alloy were used in this study bonded to three ceramic systems: Duceram (Degussa, Frankfurt, Germany); Williams (Williams Dental Co., Buffalo, NY, USA) and Noritake (Noritake Co., Tokyo, Japan).

Porcelain build-up and shear strength testing were accomplished using a stainless steel mold, which consisted of two parts: a lower base, with a vertical cylindrical perforation ( $15 \mathrm{~mm}$ high; $6 \mathrm{~mm}$ in diameter), and an upper removable portion of semi-circular form, which had a central perforation ( $3 \mathrm{~mm}$ high; $8.4 \mathrm{~mm}$ in diameter) that fit perfectly in the upper face of the lower base (2) (Fig. 1).

Thirty standard wax cylinders $(15 \mathrm{~mm}$ high; 6 $\mathrm{mm}$ in diameter) were cast from each alloy. A hightemperature phosphate-bonded investment (Termocast, Polidental Ltd., São Paulo, SP, Brazil) was used and, 45 min after investment (setting at room temperature), the rings were burned-out according to manufacturer instructions. Alloys were melted in individual crucibles with a multiorifice gas-oxygen torch and cast in a broken-arm centrifugal casting machine (Kerr/Sybron,
Romulus, MI, USA), with its arm set at four turns. After casting, each ring was bench-cooled and the casting pieces were divested. The specimens were cleaned with $50-\mu \mathrm{m}$ glass beads in a non-recycling machine (Trijato, Labordental Ltd., São Paulo, SP, Brazil). After casting, each ring was allowed to cool to room temperature and the casting pieces were divested. The removal of casting residues was made with sandblasting with 50 $\mu \mathrm{m}$ glass beads and aluminum oxide mixture with a Trijet machine (Labordental, São Paulo, SP, Brazil). Thirty specimens of each of the three $\mathrm{Ni}-\mathrm{Cr}$ alloys were obtained.

After the cast pieces were cleaned, the buttons of the specimens were cut with aluminum oxide disks (Dentorium International Inc., New York, NY, USA) and their extremities were shaped to make them parallel to each other. The other surfaces of the specimens were finished to fit in the mold base. After fitting of the specimens, each surface was rubbed with an aluminum oxide stone and blasted with aluminum oxide jets at 80 psi $(0.541 \mathrm{MPa})$. To prevent any possible contamination, the specimens were immersed in distilled water in an ultra-sound machine (Mini Sono Cleaner CA 1470; Kaijo Denki Co. Ltd., Tokyo, Japan) for $10 \mathrm{~min}$.

Porcelain build-up followed two sequences, i.e., one for the opaque and the other for the body, according to the manufacturer's instructions for temperatures and atmospheric conditions. The cylindrical specimens were positioned in the lower half of the mold, with approximately half of its height above that. As the upper part of the mold, with circular form, presents a hole with an $8.4 \mathrm{~mm}$ diameter and a $3.0 \mathrm{~mm}$ height, it

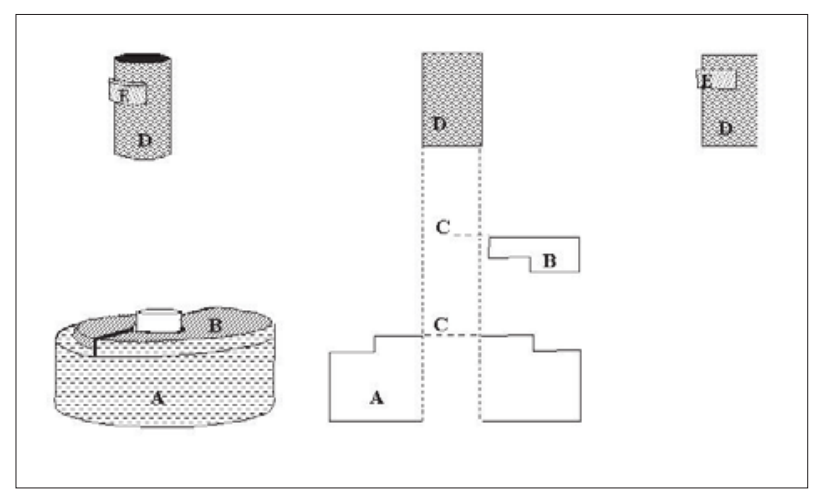

Figure 1. Schematic drawing of the stainless steel mold used for specimen preparation, porcelain application and shear strength testing. A: Lower portion. B: Upper portion. C: Central cylindrical perforation. D: Tested Specimen. E: Porcelain layer. 
provided a porcelain layer with similar dimensions for all specimens, that is, $1.2 \times 3.00 \mathrm{~mm}$, with an area of $0.2827 \mathrm{~cm}^{2}$ (Fig. 2). Thirty specimens were obtained from each porcelain system, i.e., 10 specimens of each tested alloy, making up a total of 90 specimens. The procedures for porcelain firing are given in Table 1.

After firing, porcelain finishing was accomplished with diamonded burs and, a second build up of body porcelain was performed. To make those procedures uniform, the specimens were taken to the oven for the third time, with the same temperatures and atmospheric conditions previously used.

After the applied porcelain area was measured, the lower part of the mold was taken the specimen to an universal testing machine (EMIC model MEM 2000; Emic Equipment and Test Systems Ltd., São José of Pinhais, PR, Brazil). The test configuration was then loaded in shear strength, with generation of forces perpendicular to the ceramic metal interface at a crosshead speed of $0.5 \mathrm{~mm} / \mathrm{min}$ until failure occurred and failure loads were recorded in $\mathrm{MPa}$.

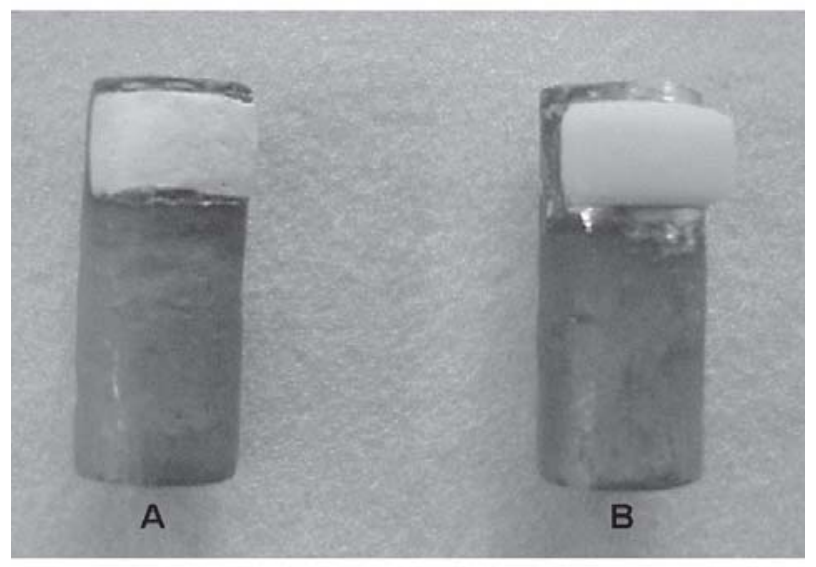

Figure 2. Specimens with the opaque (A) and porcelain body after firing (B).

Table 1. Porcelain firing cycles.

\begin{tabular}{|c|c|c|c|c|c|c|}
\hline \multirow[t]{3}{*}{ Porcelain } & \multicolumn{3}{|c|}{ Opaque bakes } & \multicolumn{3}{|c|}{ Body bakes } \\
\hline & \multicolumn{3}{|c|}{ Temperature } & \multicolumn{3}{|c|}{ Temperature } \\
\hline & Initial & - & Final & Initial & - & Final \\
\hline Duceram & $750^{\circ} \mathrm{C}$ & - & $980^{\circ} \mathrm{C}$ & $750^{\circ} \mathrm{C}$ & - & $960^{\circ} \mathrm{C}$ \\
\hline Williams & $540^{\circ} \mathrm{C}$ & - & $980^{\circ} \mathrm{C}$ & $540^{\circ} \mathrm{C}$ & - & $960^{\circ} \mathrm{C}$ \\
\hline Noritake & $650^{\circ} \mathrm{C}$ & - & $990^{\circ} \mathrm{C}$ & $650^{\circ} \mathrm{C}$ & - & $940^{\circ} \mathrm{C}$ \\
\hline
\end{tabular}

Compressive force was applied to the upper portion of the specimens and stress was produced in the opaque/metal interface. It generated a shear strength that was calculated by dividing the applied force at the failure by the surface area of the opaque layer (Fig. 3).

Data obtained from shear testing were analyzed statistically. Mann-Whitney U non-parametric test was used to verify whether or not there was statistically significant difference among the combinations at $5 \%$ significance level.

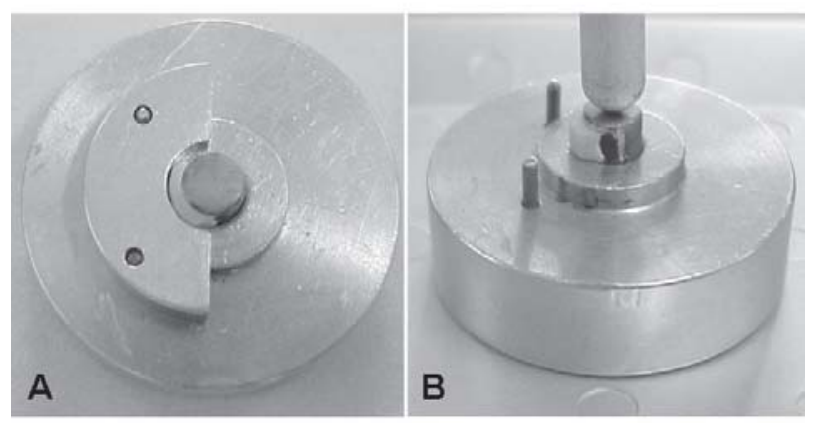

Figure 3. a) Specimen positioned into the mold, after porcelain build-up; b) Specimen being submitted to the shear strength test.

\section{RESULTS}

Shear bond strengths of the combinations of nickel-chromium alloys and ceramic systems are given in the Table 2.

Viron/Noritake differed statistically from other combinations $(\mathrm{p}<0.05)$. Viron/Duceram had statistically significant higher bond strengths than Verabond/ Duceram, Verabond/Williams and Durabond/Noritake $(\mathrm{p}<0.05)$.

It was also observed statistically significant difference $(\mathrm{p}<0.05)$ between Verabond/Noritake, Verabond/Duceram and Durabond/Noritake. However,

Table 2. Shear strength means of alloy/porcelain union (MPa).

\begin{tabular}{lccc}
\hline Porcelain & \multicolumn{3}{c}{ Alloys } \\
\cline { 2 - 4 } & Viron & Verabond & Durabond \\
\hline Duceram & 24.33 & 16.31 & 19.41 \\
Willians & 19.86 & 19.07 & 19.97 \\
Noritake & 32.93 & 22.30 & 17.52 \\
\hline
\end{tabular}


no statistically significant difference $(p>0.05)$ were observed among the other combinations (Table 3 ).

Table 3. Individual comparisons of the interactions significant at 5\% level by Mann-Whitney U test.

\begin{tabular}{lc}
\hline $\begin{array}{l}\text { Interactions between the } \\
\text { combinations of materials }\end{array}$ & $\begin{array}{c}\text { Mann-Whitney } \\
\text { U test }\end{array}$ \\
\hline Viron + Duceram X Viron + Noritake & 0.0173 \\
Viron + Duceram X Verabond + Duceram & 0.0073 \\
Viron + Duceram X Verabond + Willians & 0.0376 \\
Viron + Duceram X Durabond + Noritake & 0.0036 \\
Viron + Willians X Viron + Noritake & 0.0028 \\
Viron + Noritake X Verabond + Duceram & 0.0004 \\
Viron + Noritake X Verabond + Willians & 0.0008 \\
Viron + Noritake X Verabond + Noritake & 0.0091 \\
Viron + Noritake X Durabond + Duceram & 0.0013 \\
Viron + Noritake X Durabond + Willians & 0.0022 \\
Viron + Noritake X Durabond + Noritake & 0.0002 \\
Verabond + Duceram X Verabond + Noritake & 0.0376 \\
Verabond + Noritake X Durabond + Noritake & 0.0173 \\
\hline
\end{tabular}

\section{DISCUSSION}

A constant concern observed in the literature has been the attempt to explain the nature of the composition that promotes adhesion at metal/ceramic interface because technical perfection relies on successful bonding in this region (5-10). This perhaps is the reason for the expressive studies evaluating metal/ceramic bonding with increasingly greater precision and in a simplified way $(1,2,8,11-14)$.

The fact that dental prosthesis technicians and dentists often have to make several associations of national and foreign metal alloys and ceramic systems gave rise to our interest in evaluating the resistance of metal/porcelain adhesion, in an attempt to overcome the lack of information about these materials. Professionals must carefully select the metal/porcelain systems to be combined (15) when planning the use of base alloys for the metal-ceramic restorations.

This study compared the shear bond strength of different combinations of ceramic systems tested and $\mathrm{Ni}-\mathrm{Cr}$ alloys. Significant differences were found among them, Viron/Noritake presenting the highest shear bond strength (32.93 MPa) and Verabond/Duceram (16.31 $\mathrm{MPa}$ ) presenting the lowest means. Data obtained for Viron metal alloy and Duceram system are in agreement with the findings of a previous study (16). It is important to point out that few studies have been carried out with the Duceram and Williams systems, mostly comparing these materials with other commercially available ceramic systems. Fernandes Neto (17) compared four different alloys in association with three ceramic systems and found that Duceram bonded to Resistal $\mathrm{P}$ alloy presented the best results. However, no statistically significant difference was observed when this combination was compared to Duceram/Durabond or to the association between an experimental alloy and Vita VMK 88 or Duceram. In this study, Duceram had an average performance, with lower bond strength than Noritake system. These results are possibly due to the expansion curves and residual contraction of these system $(11,18)$. Fernandes Neto (17) and Yilmaz and Dinçer (9) also found that alloys with titanium could increase the bond strength of dental porcelains.

The findings of this study showed that the Viron alloy had the best performance, followed by Verabond and Durabond. Hammad et al. (13) reported lower bond strength for Vita VMK 88/Durabond alloy when the alloy was submitted to previous oxidation. These observations are in agreement with those of other reports that observed the existence of significant differences among several commercially available brands of $\mathrm{Ni}-\mathrm{Cr}$ based alloys $(12,14,15,18)$. Therefore, comparisons of the results of studies using different materials are not reliable because of variations in the mechanical properties of the alloys, heating method used for casting or the number of times the alloy was melted (19). In addition, it is important to point out that the strength of the framework does not depend exclusively on the alloy used but also on its design $(14,18)$. Frameworks with sharp and much defined forms commonly have very low fracture strength (14). Therefore, although it is well recognized which general physical properties an ideal alloy should have, it is not possible to make a recommendation to the clinician about which currently available alloys should preferably be used in metal ceramic restorations (20).

In this study, the Noritake ceramic system used together with Viron alloy presented the highest resistance to shear forces, while Duceram bonded to Verabond presented the lowest bond strength. Viron/Duceram and Verabond/Noritake provided intermediate results. The combinations between the Williams ceramic system and Ni-Cr alloys had similar shear strengths among each other. 
Although bond strength data like these can be helpful at clinical level for selection of the most suitable materials to be used, it is important to highlight that, due to the continuous introduction of new metal alloys and ceramic systems, constant studies should be carried out to assess the compatibility of metal/ceramic combinations. This means that, both metal alloys and ceramic systems tested in this study can present higher shear strength if combined with other materials, or tested through techniques specifically developed for each type of alloy or porcelains available.

\section{RESUMO}

Devido ao contínuo avanço tecnológico e crescente disponibilidade de novas ligas não-nobres e sistemas cerâmicos no mercado, e também à prática clínica diária, a constante avaliação da resistência de união das combinações metal/porcelana tornou-se necessária. Este estudo avaliou a resistência da união metal/porcelana de três sistemas cerâmicos (Duceram, Williams e Noritake) em combinação com três ligas à base de níquel-cromo $(\mathrm{Ni}-\mathrm{Cr})$ (Durabond, Verabond e Viron). Trinta cilindros fundidos (15 mm de altura; $6 \mathrm{~mm}$ de diâmetro) foram obtidos para cada liga e 10 espécimes de cada liga foram testados com cada porcelana. A resistência de união foi calculada utilizando uma máquina EMIC aplicando uma força de cisalhamento paralela ao corpo-de-prova até a fratura. A resistência ao cisalhamento foi calculada usando a força aplicada dividida pela área de superfícia da camada de opaco. O teste U de Mann-Whitney foi empregado para a análise estatistica das interações metal/porcelana $(p<0,05)$. Viron/ Noritake apresentou a maior média de resistência adesiva (32,93 $\mathrm{MPa}$ ), enquanto Verabond/Duceram apresentou a menor média (16,31 MPa). Viron/Noritake diferiu estatisticamente das demais combinações $(p<0,05)$. Viron/Duceram apresentou média estatisticamente maior que Verabond/Duceram, Verabond/ Williams e Durabond/Noritake $(p<0,05)$. Houve diferença significante $(\mathrm{p}<0.05)$ também entre Verabond/Noritake, Verabond/ Duceram e Durabond/Noritake. Não houve diferença estatisticamente significante entre as demais combinações ( $p>0,05)$. Em conclusão, o sistema cerâmico Noritake utilizado em associação com a liga Viron apresentou a maior resistência às forças de cisalhamento, enquanto o sistema Duceram em combinação com a liga Verabond apresentou a menor média de resistência ao cisalhamento. Viron/Duceram e Verabond/Noritake promoveram resultados intermediários. As combinações entre o sistema cerâmico Williams e as ligas de Ni-Cr apresentaram médias de resistência ao cisalhamento semelhantes entre si.

\section{REFERENCES}

1. Moffa JP, Guckes AD, Okawa MT, Lilly GE. An evaluation of nonprecious alloys for the use with porcelain veneers. Part. I. Physical properties. J Prosthet Dent 1973;30:424-431.

2. Sced IR, McLean JW. The strength of metal/ceramic bonds with base metals containing chromium. Brit Dent J 1972;132:232-234.
3. Bezzon OL, Ribeiro RF, Rollo JMDA, Crosara S. Castability and resistence of ceramometal bonding in $\mathrm{Ni}-\mathrm{Cr}$ and $\mathrm{Ni}-\mathrm{Cr}-\mathrm{Be}$ alloys. J Prosthet Dent 2001;85:299-304.

4. Bezzon OL, Mattos MGC, Ribeiro RF, Rollo JMDA. Effect of beryllium on the castability and resistence of ceramometal bonds in nickel-chromium alloys. J Prosthet Dent 1998;80:570-574.

5. Anusavice KJ, Horner JA, Fairhurst CW. Adherence controlling elements in ceramic-metal system. I. Precious alloys. J Dent Res 1977;56:1045-1052.

6. Anusavice KJ, Ringle RD, Fairhurst CW. Adherence controlling elements in ceramic-metal systems. II: Nonprecious alloys. J Dent Res 1977;56:1053-1061.

7. McLean JW. The metal ceramic restoration. Dent Clin N Amer 1983;27:747-761.

8. Chong MP, Beech DR, Chem CA. A simple shear test to evaluate the bond strength of ceramic fused to metal. Aust Dent J 1980;25:357-361.

9. Yilmaz H, Dinçer C. Comparison of the bond compatibility of titanium and an Ni-Cr alloy to dental porcelain. J Dent 1999;27:215-222.

10. Chiodi Netto J. Avaliação da resistência de união da porcelana aplicada sobre liga de Ni-Cr e sobre solda. [Doctoral Thesis]. Bauru: Faculdade de Odontologia de Bauru, Universidade de São Paulo; 1981. 196 p.

11. Papazoglou E, Brantley WA, Johnston WM, Carr AB. Effects of dental laboratory processing variables and in vitro testing medium on the porcelain adherence of high-paladium casting alloys. J Prosthet Dent 1998;79:514-519.

12. Carter JM, AL-Mudafar J, Sorensen SE. Adherence of a nickelchromium alloy and porcelain. J Prosthet Dent 1979;41:167172 .

13. Hammad IA, Goodkind RJ, Gerberich WW. A shear test for bond strength of ceramometals. J Prosthet Dent 1987;58:431-437.

14. Schaffer SP. An approach to determining the bond strength of ceramometal system. J Prosthet Dent 1982;48:282-284.

15. Warphea WS, Goodkind RJ. Design and technique variables affecting fracture resistance of metal-ceramic restorations. J Prosthet Dent 1976;35:291-298.

16. Lubovich RP, Goodkind RJ. Bond strength studies of precious, semiprecious, and nonprecious ceramic-metal alloys with two porcelains. J Prosthet Dent 1977;37:288-299.

17. Fernandes Neto AJ. Avaliação da resistência de união de três sistemas de porcelana odontológica aplicados sobre três ligas à base de $\mathrm{Ni}-\mathrm{Cr}$ e uma à base de $\mathrm{Co}-\mathrm{Cr}$ contendo Titânio. [Doctoral Thesis]. Ribeirão Preto: Faculdade de Odontologia de Ribeirão Preto, Universidade de São Paulo; 1996. 103 p.

18. Nally JN. Chemico-physical analysis and mechanical test of the ceramo-metallic complex. Int Dent J 1968;18:309-325.

19. Daftary F, Donovan T. Effect of four pretreatment techniques on porcelain-to-metal bond strength. J Prosthet Dent 1986;56:535-539.

20. Lewis AJ. The effects of remelting on the mechanical properties of a nickel base partial denture casting alloy. Aust Dent J 1975;20:89-93. 